
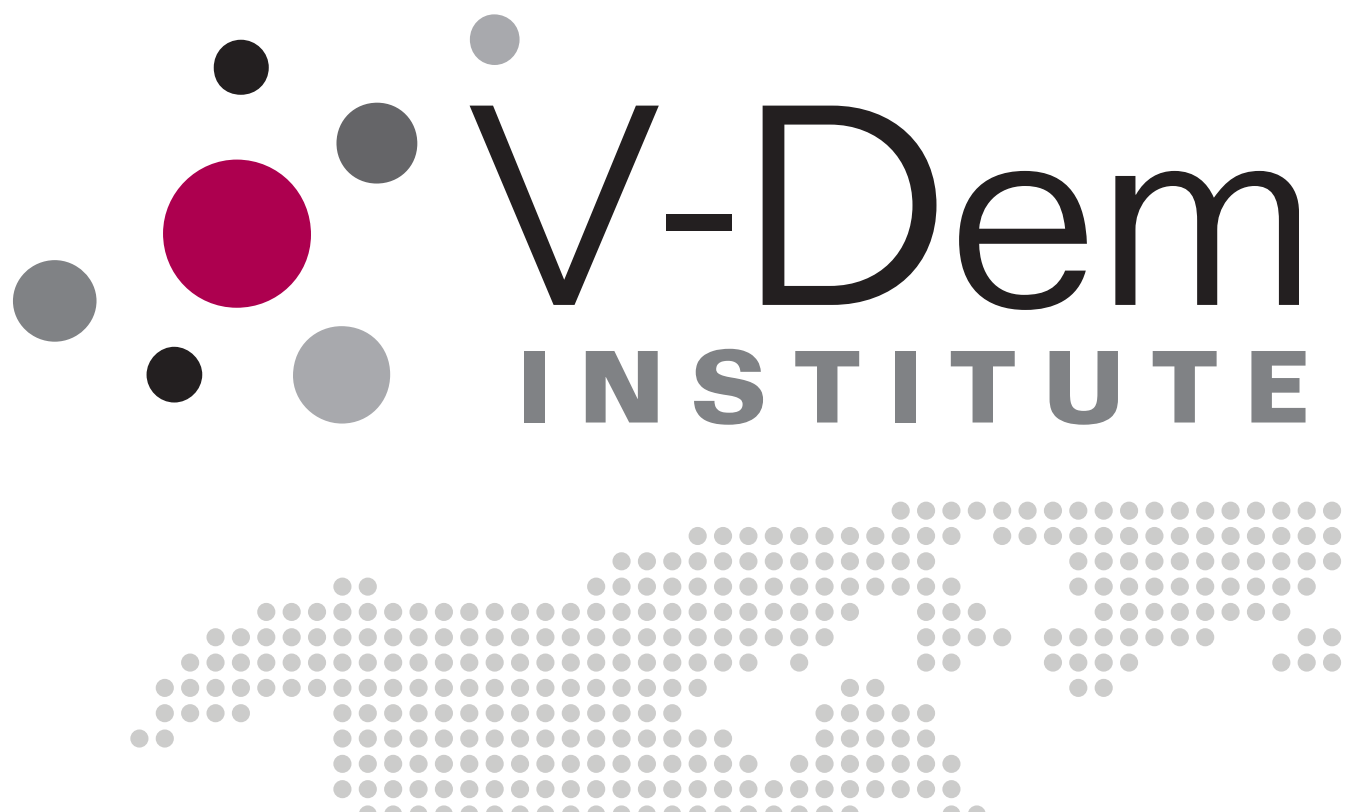 100900
100

-

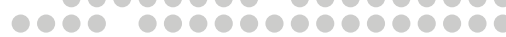

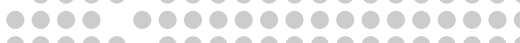

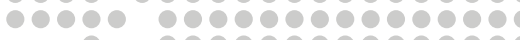
00

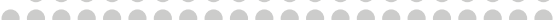

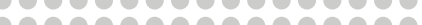

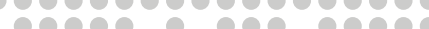

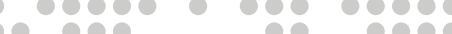

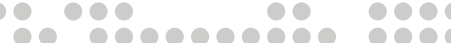

The V-Dem Party Institutionalization Index: a new global indicator $(1900-2015)$

Fernando Bizzarro, Allen Hicken, Darin Self

000000000

1000000

1000000

090000

10000

000

000

10

10

10

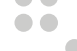

May 2017

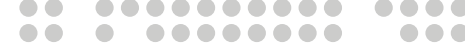

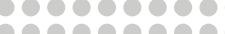

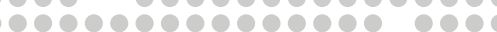

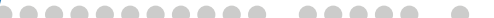

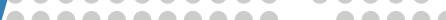

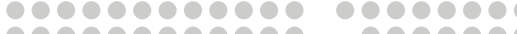

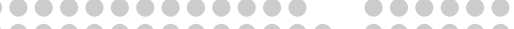

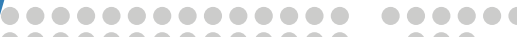
190000000000000 1000000000000000

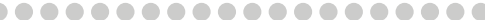

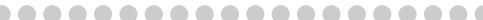
-

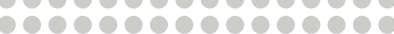

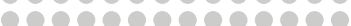

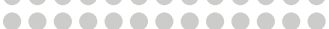

10000000000

0000000000

000000000

-

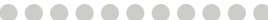

60000000000

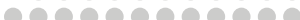
-

-

- 0900000

0000000

100000

000000

000

00

10 10 
Varieties of Democracy (V-Dem) is a new approach to the conceptualization and measurement of democracy. It is co-hosted by the University of Gothenburg and University of Notre Dame. With a V-Dem Institute at University of Gothenburg that comprises almost ten staff members, and a project team across the world with four Principal Investigators, fifteen Project Managers, 30+ Regional Managers, 170 Country Coordinators, Research Assistants, and 2,500 Country Experts, the V-Dem project is one of the largest-ever social science research-oriented data collection programs.

Please address comments and/or queries for information to:

V-Dem Institute

Department of Political Science

University of Gothenburg

Sprängkullsgatan 19, PO Box 711

SE 40530 Gothenburg

Sweden

E-mail: contact@v-dem.net

V-Dem Working Papers are available in electronic format at www.v-dem.net.

Copyright (C) 2017 by authors. All rights reserved. 


\title{
The V-Dem Party Institutionalization Index: \\ a new global indicator (1900-2015) ${ }^{*}$
}

\author{
Fernando Bizzarro ${ }^{1}$ \\ PhD Student \\ Harvard University \\ Allen Hicken \\ Associate Professor \\ University of Michigan \\ Darin Self \\ PhD Student \\ Cornell University
}

\footnotetext{
${ }^{*}$ This research project was supported by Riksbankens Jubileumsfond, Grant M13-0559:1, PI: Staffan I. Lindberg, VDem Institute, University of Gothenburg, Sweden; by Knut and Alice Wallenberg Foundation to Wallenberg Academy Fellow Staffan I. Lindberg, Grant 2013.0166, V-Dem Institute, University of Gothenburg, Sweden; as well as by internal grants from the Vice-Chancellor's office, the Dean of the College of Social Sciences, and the Department of Political Science at University of Gothenburg. We performed simulations and other computational tasks using resources provided by the Notre Dame Center for Research Computing (CRC) through the High Performance Computing section and the Swedish National Infrastructure for Computing (SNIC) at the National Supercomputer Centre in Sweden, SNIC 2016/1-382 and 2017/1-68. We specifically acknowledge the assistance of In-Saeng Suh at $\mathrm{CRC}$ and Johan Raber at SNIC in facilitating our use of their respective systems.

1 Corresponding Author. E-mail: fbizzarroneto@g.harvard.edu. Department of Government, Harvard University. 1737 Cambridge Street, Cambridge MA. 02138.
} 


\section{Abstract}

Because levels of party institutionalization may affect the availability of good data, existing datasets have limited reliability and coverage. To overcome these problems, we introduce the V-Dem Party Institutionalization Index, the first global country-level index on the issue. It covers - as of May 2017 - 173 countries for 116 years (1900-2010). Its geographical coverage, timespan, and conceptual reach are larger than any existing alternative. We offer an additive index that measures the scope and depth of party institutionalization in a country every year. Scope is measured by the proportion of parties that reach a threshold of minimal institutionalization, while the linkages party establish with the masses and the elites define the depth. Exploring a set of well-known cases, we show that: the index has extensive face validity, is consistent across regime types, and is comparable to other established indicators of institutionalization.

\section{Introduction}

Political parties are ubiquitous in modern polities. They lie at the core of modern democracy (Schattschneider, 2003), and an increasing number of authoritarian regimes have also become party-based (Svolik, 2012, Levitsky and Way, 2010). Parties are also some of the most consequential political institutions, affecting regime survival (Bernhard et al., 2015, Mainwaring and Scully, 1995, Brownlee, 2007, Magaloni, 2006, Gandhi, 2008), economic outputs (Bizzarro et al., 2015, Gehlbach and Keefer, 2011, Gehlbach and Keefer, 2012, Miller, 2015, Hicken, 2016), and the likelihood of internal violent conflicts (Fjelde, 2010). Despite this excellent work, one of the major challenges for the further advancement of the scholarship on political parties and their consequences has been the absence of good comparative data (Poguntke et al., 2016).

Existing datasets have limited time and space coverage, and due to the intensive work involved in carefully collecting information on this topic, existing indicators tend to measure only one of the many dimensions on which parties and party systems vary (Tavits, 2013). Additionally, because the availability of good data on political parties could itself be a function of the nature of a party system, issues of data reliability and measurement error are always present - although often ignored.

In this article, we present a new country-level index of party institutionalization developed in the context of the Varieties of Democracy project (Coppedge et al., 2016b). The V-Dem Party Institutionalization Index stands out as the first global index on the issue, covering - as of May 2017 - 173 countries for a maximum of 115 years (1900-2015). It extends far beyond any existing indicator in terms of geographical coverage, timespan, and conceptual reach.

We propose a three-dimensional index, measuring: 1) the scope of party institutionalization in a country, 2) the proportion of parties that reach a threshold of minimal institutionalization, and 3) variations in the depth of this institutionalization - focusing on the links parties establish with voters and elites. The final additive 
index we create reflects these dimensions. Two features of the index are notable and unique. First, it consistently measures party institutionalization in democracies and autocracies. Second, it takes advantage of the unique research design of the V-Dem project, employing state-of-the-art practices for cross-national data collection of political indicators (Coppedge et al., 2016c). We argue that those features make the V-Dem Party Institutionalization Index the most empirically and theoretically robust measurement tool for the comparative analysis of parties and party systems available.

\section{Party Institutionalization}

Political parties are complex organizations. While there are minimalist definition of political parties, like Anthony Downs' "parties are group of men competing for political power in elections," (Downs 1957), the examination of political parties as real world political organizations suggests that parties are complex, multifaceted organizations that often defy simply definition or classification. At the most basic level, parties are composed of political elites, they engage in election activities, and they manage political power (Key, 1964, Katz, 1980). But beyond this minimalist set of characteristics parties vary widely. Individual parties may invest more time and resources in developing one of those three basic facets, and parties with different emphases tend to be organized and behave very differently (Müller and Strøm, 1999). Moreover, parties have increasingly been important actors in autocracies, where they may or may not participate in elections (Magaloni, 2006, Svolik, 2012).

Comparing such a variegated set of organizations is a complicated task. One way to approach this comparison is asking about parties' degree of institutionalization. Although definitions of institutionalization vary from author to author, most of them derive from Huntington's (1968) or Panebianco's (1988) work. The two definitions have in common a focus on temporal stability - institutionalization is a process by which organizations become stable and survive over time without major changes - and the argument that organizations acquire a long term value - political elites, party members, and voters, value parties for their long term contributions, and are willing to sacrifice their short-term objectives for the party's long term goals (Levitsky, 2003, Basedau and Stroh, 2008). Huntington calls this dimension of institutionalization "valueinfusion", while Panebianco associates it with passage between different modes of party organization.

We diverge slightly from the literature and understand institutionalization not as a process - which implies a diachronic concept - but rather as a measure of the degree to which a party approximates an ideal type. The more similar the party is to this ideal type, the more institutionalized it is. Our ideal, type, however, assumes many of the characteristics authors like Huntington and Panebianco attributed to countries that experienced the "process of institutionalization". 
First, Institutionalized parties are stable. Stability, however, needs to be understood in very specific terms, and we argue that the most fruitful way is to evaluate the degree to which parties constitute stable organizations.

Second, institutionalized parties impose the parties' long-term goals over individual elites' short-term goals. This is how we understand the notion of "value-infusion". Parties become larger than their members, and their survival are valued by all members regardless of the parties' short-term contribution to individual careers. The challenge, of course, is that the payoffs elites extract from affiliating with a party cannot be directly measured, since it is a function of each individual elite's subjective evaluation of the party's value. What can be measured is the behavior of actual elites: when they sacrifice their individual short-term interests to the parties' interests, this signals the supremacy of the party over the individual politician.

Third, we acknowledge that parties matter beyond their role in elite politics, playing a crucial role in connecting and mobilizing the public (Sartori, 2005, Smith, 2005). Those connections mimic the relationship elites have with their parties: voter-party connections can be more or less stable, and more or less long-term oriented. When connections between parties and voters are more stable and more long-term oriented, we expect parties to be more institutionalized.

In this discussion, we interact with the large literature focusing on the institutionalization of individual parties. However, party institutionalization also has important consequences for systemic institutionalization. The degree of institutionalization of the set of parties in one given polity contributes to the level of party system institutionalization. Hicken and Kuhonta (2014) treat party institutionalization as the central "internal dimension" of system institutionalization. Mainwaring and his co-authors (Forthcoming) go further as they separate party system institutionalization - i.e., the stability in the set of actors and in the patterns of competition among them - from party institutionalization, arguing that the latter works is a causal underpinning of the former. We follow this logic in the present article.

\section{Measuring Party Institutionalization}

Appropriately measuring characteristics of political regimes is a major challenge for contemporary political science. Political institutions are multifaceted, sometimes internally contradictory, and are the product of a series of historically bounded processes. Finding valid and reliable ways to comparatively assess levels and changes in these institutions has inspired major research projects in the discipline for many years (Coppedge et al., 2011). Among those projects, a handful of them have focused on political parties and party systems, offering remarkably valuable data about parties' organizational characteristics and policy preferences, and about party systems' dynamics and stability (Kitschelt, 2013, Volkens et al., 2016, Poguntke et al., 2016, Mainwaring et al., 2016, Basedau and Stroh, 2008, Kollman et al., 2016). 
All these efforts however, have encountered important practical limits. Parties are the most widespread political institution in the world and they vary widely even within territorial units. Official sources of information about parties are rare. Autocracies have few incentives to publicize information about the ruling party. In democracies, the separation between parties and the state usually leaves a large part of the burden for archiving and publicizing relevant data to the parties themselves, and making this information available is not typically a priority for those parties. Moreover, the availability of data about parties is most likely correlated with their degree of institutionalization - more institutionalized parties tend to be better at producing and storing systematic information - increasing the challenges for data collection efforts, and hampering our ability to draw inferences from the data we do collect. These challenges have limited the available data about political parties to specific regions of the world or to a limited set of indicators (Tavits, 2013).

The V-Dem project overcomes these limits in two ways. First, rather than relying on primary data about parties, V-Dem recruited a team of almost 3,000 experts to collaborate on a joint effort to code multiple regime characteristics (Coppedge et al., 2016c). Guided by the principles of multidimensionality, disaggregation, and transparency, V-Dem relied on expert knowledge of 173 countries to collect information about the configuration of political institutions in the world for the last 115 years. Those experts answered a set of questions in a survey designed to clearly and unambiguously delineate the characteristics of 5 dimensions of democracy (electoral, liberal, egalitarian, participatory, and deliberative) as well as of additional institutional characteristics of political regimes (sovereignty, governance, and, of course, political parties). This survey and the subsequent creation of the V-Dem dataset followed some of the most advanced techniques in the field of expert surveys, producing a set of $400+$ indicators of regime characteristics.

Additionally, when asking about parties, V-Dem avoided concentrating on individual organizations and asked experts to provide "country-level" assessments. It asked about "the parties" or "the main parties" in each political system, rather than about party A or B. This allowed for more efficient and reliable data collection, ensuring the availability of global data about party organizations. In doing so, V-Dem overcame a third important challenge to the existing set of empirical indicators about political parties: aggregation. While aggregating scores for individual parties to constitute country-level indicators is usually tricky, involving intricate formulas and weights, V-Dem's approach aggregates by design, constituting a set of clear and reliable indicators for cross-national comparative analysis of political parties.

Specifically, twelve questions in the survey concerned political parties. They can be divided in 4 categories: $^{2}$ the scope of party institutionalization, the degree of party institutionalization, other characteristics of political parties, and information about the institutional environment in which parties exist. Eleven of those variables were ordinal / categorical, with categories corresponding to gradations that delineated the degree to

\footnotetext{
2 Table A1 in Appendix A contains the result of an Exploratory Factor Analysis to inductively identify the structure of the data.
} 
which a country reached a pre-defined ideal type. Coders' scores were then mapped into a continuous latent variable using a Bayesian IRT model (Pemstein et al., 2015), ensuring cross-national validity and the reliability of the indicators produced. One of the variables (Party Switch) asked voters to report continuous values on a scale. The values in the V-Dem dataset are the mean of the results reported by coders in this question.

In this article, we concentrate on five of these variables and include them on our Index of Party Institutionalization. Table 1 has the text of the questions and descriptive statistics of their final continuous version.

"Party Organizations" asks how many of the parties in a country have permanent organizations, explicitly mentioning party personnel that carry out party activities outside of elections. "Party Branches" asks a similar question, focusing on a different type of political organization: local branches. It asks how many of the parties have permanent local branches, additional evidence of the materiality of the party organization. Those two variables are highly correlated with a third, "Distinct platforms", that asked coders to provide information on how many of the parties in the system have publicly disseminated and distinct platforms. The structure of their answers is similar, varying from "none of the parties" to "all the parties". Consistently, variation in the final continuous scores reflect variation from party systems in which none or few of the parties present these characteristics (lower scores) to party systems in which most or all the parties have national organizations, local branches, and publicly available and disseminated platforms.

We claim that these three questions provide an assessment of the scope of party institutionalization within a country. It is essentially asking how many of the parties in a country present a pre-determined set of characteristics that are associated with institutionalized parties - the presence of stable national and local organizations, and of a set of commitments that the party makes to a platform and label. They directly connect to the organizational stability dimension of institutionalization discussed in the theoretical section, and they provide a sense of the proportion of the parties in each country that meet these theoretical expectations. 


\section{Table 1. Variables Included in the Index}

\section{Party organizations (v2psorgs)}

How many political parties for national-level office have permanent organizations?

\begin{tabular}{lllll} 
0: No parties. & 1: Fewer than half. & 2: About half. & 3: More than half. & 4: All parties. \\
\hline Mean & Std. Dev. & Min. & Max. & N
\end{tabular}

\begin{tabular}{lllll}
0.02 & 1.65 & -3.25 & 3.31 & 16648 \\
\hline $\begin{array}{l}\text { Party branches (v2psprbrch) } \\
\text { How many parties have permanent local party branches? }\end{array}$ \\
\begin{tabular}{lllll} 
0: No parties. & 1: Fewer than half. & 2: About half. & 3: More than half. & 4: All parties. \\
\hline Mean & Std. Dev. & Min. & Max. & N \\
-0.03 & 1.61 & -3.17 & 3.56 & 16640
\end{tabular}
\end{tabular}

\section{Distinct party platforms (v2psplats)}

How many political parties with representation in the national legislature or presidency have publicly available party platforms (manifestos) that are publicized and relatively distinct from one another?

\begin{tabular}{lllll} 
0: No parties. & 1: Fewer than half. & 2: About half. & 3: More than half. & 4: All parties. \\
\hline Mean & Std. Dev. & Min. & Max. & N \\
-0.04 & 1.66 & -3.02 & 3.52 & 16547
\end{tabular}

\section{Legislative party cohesion (v2pscohesv)}

Is it normal for members of the legislature to vote with other members of their party on important bills?

0 : Not really. Many members are elected as independents and party discipline is very weak.

1: More often than not. Members are more likely to vote with their parties than against them, but defections are common.

2: Mostly. Members vote with their parties most of the time.

3: Yes, absolutely. Members vote with their parties almost all the time.

\begin{tabular}{lllll}
\hline Mean & Std. Dev. & Min. & Max. & N \\
0.27 & 1.39 & -3.90 & 2.50 & 16462 \\
\hline
\end{tabular}

\section{Party linkages (v2psprlnks)}

Among the major parties, what is the main or most common form of linkage to their constituents?

0: Clientelistic. Constituents are rewarded with goods, cash, and/or jobs.

1: Mixed clientelistic and local collective.

2: Local collective. Constituents are rewarded with local collective goods, e.g., wells, toilets, markets, roads, bridges, and local development.

3: Mixed local collective and policy/programmatic.

4: Policy/programmatic. Constituents respond to a party's positions on national policies, general party programs, and visions for society.

\begin{tabular}{lllll}
\hline Mean & Std. Dev. & Min. & Max. & N \\
0.05 & 1.44 & -3.13 & 3.26 & 16515 \\
\hline
\end{tabular}

Source: Coppedge et al. (2016a)

To learn more about levels of institutionalization we add two variables to our index. They differ from the previous three in two ways. They are not concerned with the reach of some characteristics within the party systems. Rather, coders were asked either to concentrate on "the major parties" or on legislators. More importantly, they allow coders to distinguish among variations in parties' characteristics. We capture the degree to which political elites submit to parties' position - our second theoretical dimension - with a question 
about the degree of legislative cohesion among party members ("Party Legislative Cohesion"). Answers varied from situations of absent party discipline in legislatures to situations of full discipline.

Finally, we include an indicator that aims at measuring variations in voter-party linkages. Although those linkages can vary dramatically (Kitschelt and Wilkinson, 2007) linkages between parties and voters are often placed along a continuum that ranges from individualistic to collective connections. Following Mancur Olson's (2009) pioneering discussion about the conditions under which individuals engage in collective enterprises - like parties - scholars have acknowledged that individuals do so when they receive goods that compensate for their time and energy commitment (Panebianco, 1988). Those goods are not only material goods, they can be immaterial or ideational. Generally, however, the discussion focuses private, club and public goods. Private or selective goods are targeted to specific individuals (clientelistic connections). Public goods are targeted to large social groups or even the whole population, are the most extreme end of collective connection. Goods that target specific collective constituencies (club goods or group clientelism) are a kind of intermediate category. The variable "Party Linkages" captures this variation.

This question is adapted from a similar question used in the Democratic Accountability and Linkages Project (Kitschelt, 2013). Given the discussion in the previous section, we treat programmatic linkages as a sign of party institutionalization (because they are more stable and long-term oriented), make "club" or "locally collective" goods sign intermediate linkages, and associate clientelistic connections with lower levels of party institutionalization.

We acknowledge that clientelistic linkages can be stable. Clientelistic networks can create and perpetuate loyalties which emerge from private goods distribution (Hicken 2011). However, clientelistic connections are certainly more short-term oriented than ideology-based linkages. Moreover, those connections are extremely costly to maintain over extended periods of time. Consequently, when we consider Party Institutionalization in the terms here proposed, treating contexts with more ideological connections as showing greater institutionalization is a theoretically consistent choice. Additionally, there is a clear and positive empirical association between the Party Linkages variable as we adopt it (with values ranging from low [predominantly clientelistic] to high [predominantly programmatic]) and the other dimensions of the index. Correlations shown in Table A2 in Appendix A show positive correlations between Party Linkages and all other variables included in the Index.

Together these five variables capture central parts of the concept we want to measure. Collectively they indicate proportion of the parties in the system that have robust organizations and the extent to which the parties' long-term goals orient the behavior of elites and masses in a political system. They also capture dynamics that are specific to the concept we aim at measuring. These variables specifically measure the characteristics of parties and not the characteristics of party systems. While party system institutionalization looks at stability in the interactions between the parties (Mainwaring et al., Forthcoming), the V-Dem Party 
Institutionalization Index is concerned with patterns and variations in the organization and behavior of the political parties themselves, with nothing about their interaction being measured.

Additionally, the variables chosen are also internally consistent. Empirically they show positive associations, although they are differentiated enough to be treated individually as shown on Table A1 in the Appendix. Theoretically they all tap into the same ideas of stability and long-term dynamics that have been in the core of the concept of institutionalization since Huntington and Panebianco first formulated it.

Equally important, they resonate with existing realities and incorporate information about parties that are not time-bound. We do not use information on parties' finances or number of members, for example, which are hard to measure cross-nationally and which may be less or more relevant to assessing the institutionalization of parties at different times and places. We concentrate on a consistent set of indicators to measure the scope of Party Institutionalization (the presence of national and local organizations, and a publicly available platform) and incorporate variations in the degree of institutionalization that are not time-bound: party-cohesion among elites and programmatic connections with voters.

These measures are also consistent across different types of political regimes. Think about Sweden and China, two countries that score high in our index. In both, "all parties" (in China "all parties" is just one party) have national and local organizations, with publicly available platforms, and parties in the two countries show high levels of cohesion among elites, and establish programmatic linkages with citizens. This constitutes a unique feature of the V-Dem Party Institutionalization Index.

In line with our theoretical treatment of the concept, we use an additive strategy to aggregate the indicators. This approach follows a "logic of substitutability", in which lower values in one indicator can be compensated by higher values in the others (Coppedge, 2012). Consequently, countries where all parties are strongly institutionalized would score high in all our scope and depth questions and will have high values in the Party Institutionalization Index. At the same time, countries scoring well in only some of the five indicators will still receive higher values than countries that receive low values in all. This strategy ensures greater variation in the final index, producing meaningful differentiation between the observations. Technically speaking, we first standardize all the five variables and add them to form the new index. We then convert the final index's values to its cumulative density function. This operation bounds its values at 0 and 1 . Figure 1 depicts the operation.

\section{Figure 1. Index Structure}

PI Index = Organizations + Branches + Platforms + Leg. Cohesion + Linkages 


\section{Party Institutionalization across the Globe}

A first empirical test of our index is the alignment between the theory we developed and the data resulting from our empirical strategy. The values in the Index should - to some degree - be consistent with our shared understanding of empirical reality. If the resulting indicator suggested that the highest levels of Party Institutionalization in the world are in some African or Middle Eastern countries, well-known for the fragility of their parties, readers would rightly question the value of this indicator.

We start by analyzing Figure 2, which has the yearly global average of our index. It tells a familiar story. Global average levels have increased over time (0.34 in 1900, 0.66 in 2014), but as many authors have documented, the number of regimes with political parties has also increased: there are more democracies now, and the number of party-based authoritarianisms is larger than ever (Svolik 2012). Additionally, the little spike in the line after 1945 captures both the establishment of many authoritarian regimes with strong parties (mostly in the communist world), as well as the beginning of second wave democracies.

\section{Figure 2. Global Average of the Party Institutionalization Index (1900-2015)}

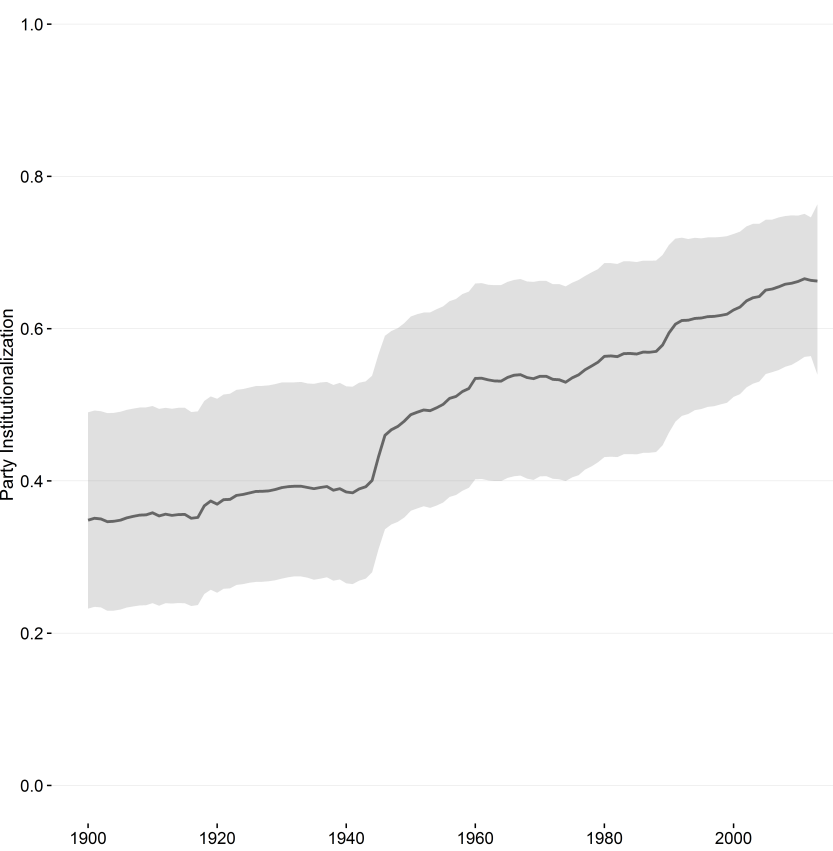

The line in Figure 2 is surrounded by a shaded area representing the 70\% High Posterior Density Interval extracted from the posterior distribution of this variable. The V-Dem measurement model estimates as its final product a distribution of the most likely values for a country-year observation. The median of this distribution is the point-estimate available in the V- 
Dem dataset and the bold line in Figure 2. The 70\% HPD serve as the confidence intervals for these estimates and are reported here and in other figures of this text. These intervals can be considered measures of uncertainty: they are an estimation of measurement error and can - and should - be incorporated in any causal inferential analysis using V-Dem data (Bizzarro, Pemstein, and Coppedge 2016). Besides the other features already introduced, measures of uncertainty are an additional component of the V-Dem dataset that makes it stand out among the existing indicators of political institutions.

Figure 3 breaks down averages by region. All regions experienced increased levels of party institutionalization in comparison to the beginning of the century, even the consolidated democracies in Western Europe, North America, and Oceania (West) - where some argue that parties have declined (Ignazi, 1996). The only region where levels of party institutionalization were lower in 2010 than in 1950 is Eastern Europe, where the collapse of the Communist regimes with strongly institutionalized parties - led to the emergence of multiparty democracies that had notoriously weaker parties, particularly during the 1990s (Grzymala-Busse, 2002).

\section{Figure 3. Regional Averages of Party Institutionalization}

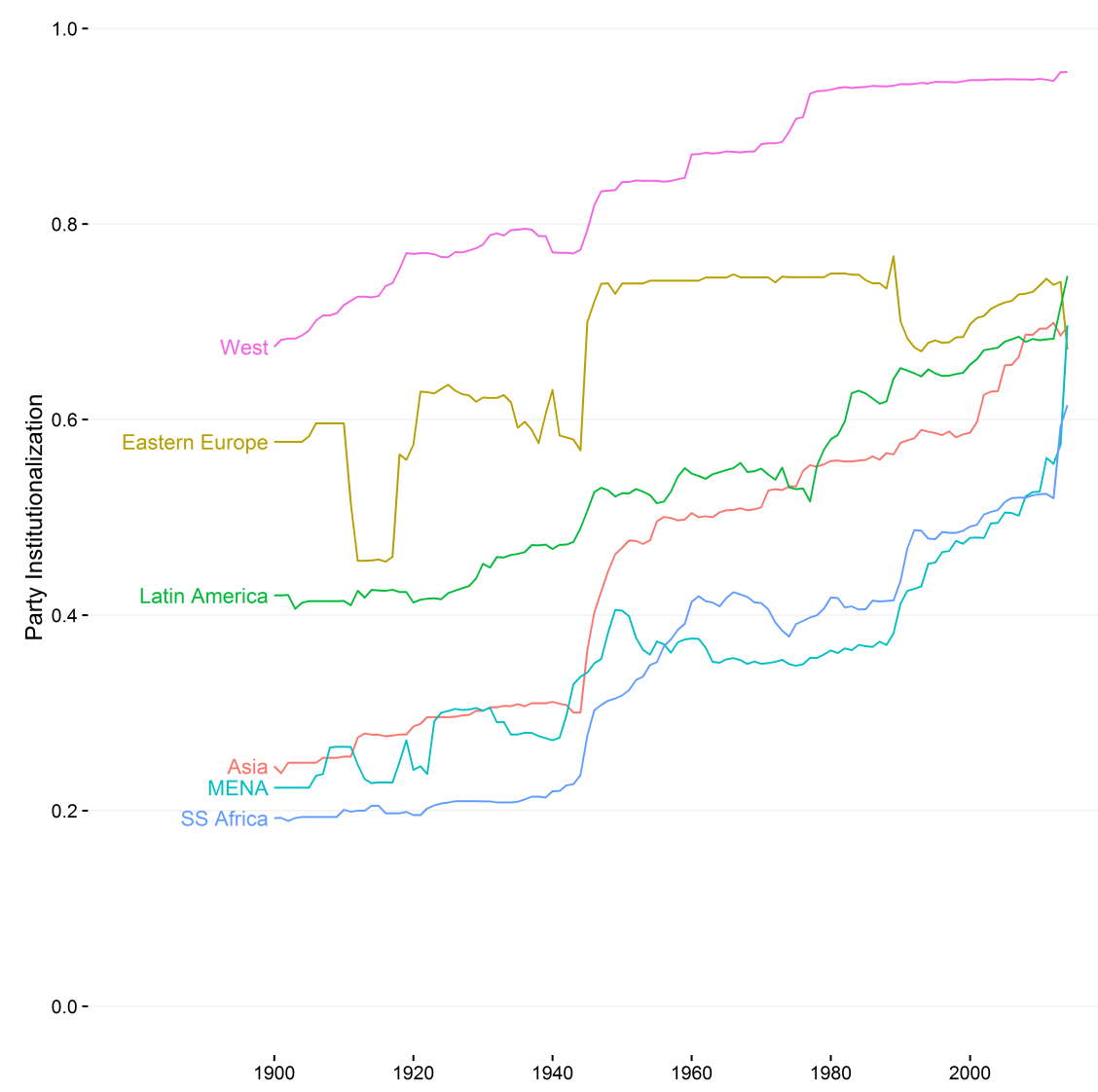


Figure 4 offers further confirmation of the argument that global and regional changes might be influenced by the changes in the sample of countries where parties are organized. We use Boix, Miller and Rosatto's dichotomous regime classification (2012) to separate authoritarian from democratic regimes, and plot the regime averages for our Index of Party Institutionalization for the 1900-2015 period. While the average level of institutionalization in democracies decreases between the early $20^{\text {th }}$ century, when just few democracies existed, and the end of the series, the average for autocracies increases, reflecting the rise of party-based authoritarian regimes, with some variation around the moments in which communist regimes emerged, and collapsed.

\section{Figure 4. Regime Averages of Party institutionalization}

$1.0-$
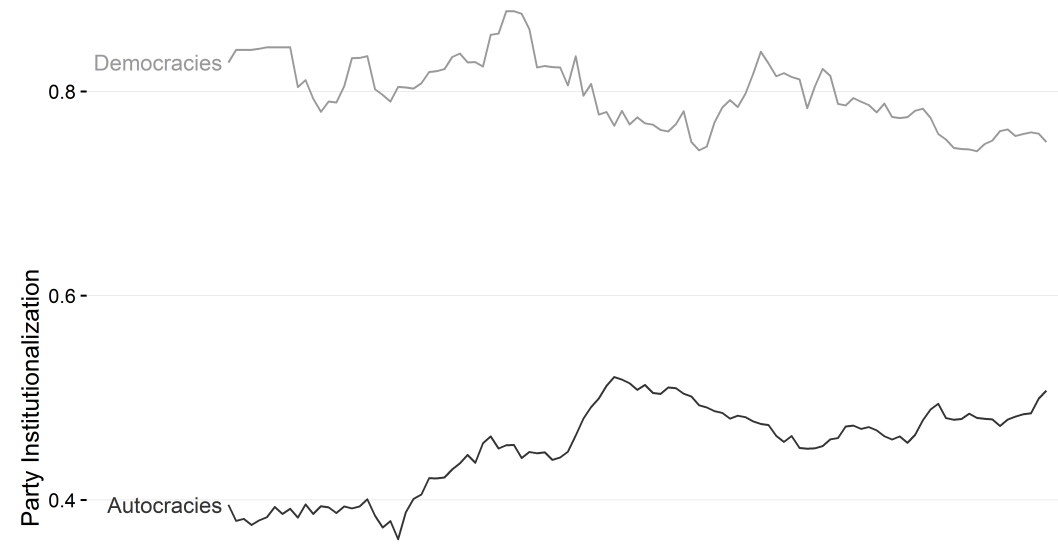

$0.2-$

$0.0-$ $199^{\prime} 00 \quad 19^{\prime} 20 \quad 19^{\prime} 40 \quad 19^{\prime} 60 \quad 1980 \quad 2000$

We also compared our Index to Geddes, Wright, and Frantz (2014) regime typology. We collapsed all the categories where parties are mentioned (party, party-military, party-personal, party-military-personal) in one "party-based" regime characteristic and compared the average level of Party Institutionalization in country-years coded as such in the GWF dataset against years coded otherwise (personal, military, oligarchy, monarchy, and their combinations). We found a statistically significant difference between the two means: on average, authoritarian regimes not 
party-based have scores in our Party Institutionalization Index 38\% smaller than the party-based authoritarianisms in their sample.

Additional information about the association between regime type and levels of Party Institutionalization can be observed in Figure 5. It plots Party Institutionalization (y-axis) against the Polyarchy score (x-axis), V-Dem's main electoral democracy index. As expected, there are both Autocracies and Democracies that score high in terms of Party Institutionalization. Interestingly, this is not the case at the opposite end of our index. While there are many authoritarian regimes with low levels of Party Institutionalization, the right-bottom corner of the graph is empty. Very democratic countries tend also to have very institutionalized parties.

\section{Figure 5. Party Institutionalization and Polyarchy}

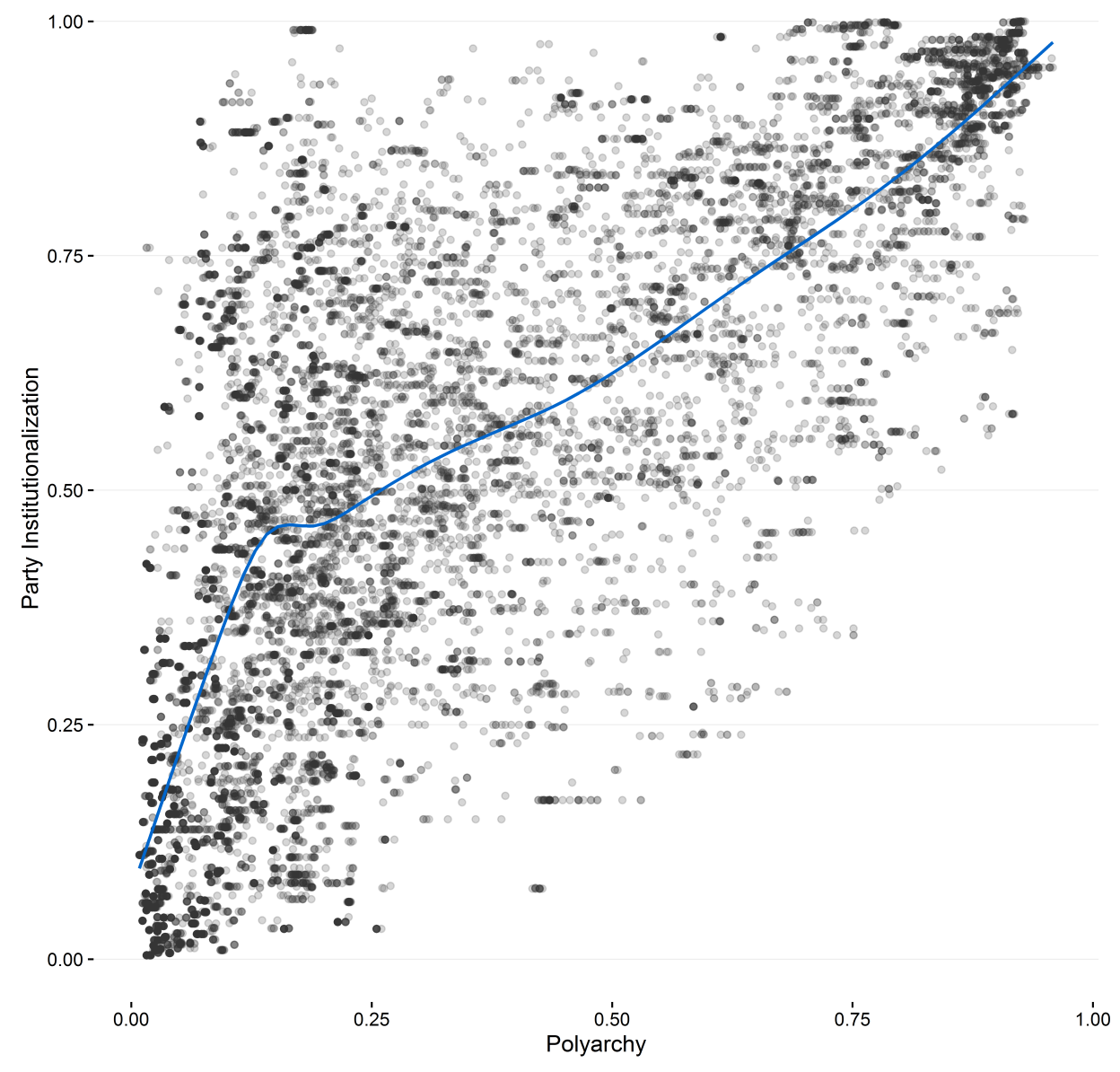




\section{Party Institutionalization in Selected Countries}

To provide additional illustrations of the V-Dem Party Institutionalization Index, we selected three sets of countries to explore in depth. These explorations aim at clarifying the potential - and the limits - of our index, relying on our common knowledge about a set of familiar cases. We start by analyzing levels of Party Institutionalization in two (contemporary) democracies: Brazil and the United States. We then change our focus to authoritarian regimes, and briefly analyze the scores of the Index for two authoritarian regimes: Bulgaria under Communism and Cuba since 1959. Finally, we take advantage of Basedau and Stroh's (2008) index of Party Institutionalization for a set of African countries and compare the scores they produce to the scores in our index. Consequently, this section provides an overview of how the index performs in different contexts and how it compares to alternative measures of the same concept already available.

Starting with the democratic regimes in Brazil and the United States (Figure 6), we are reminded that the countries experience major differences in the degree of their party institutionalization. While American parties are among the oldest in the world, scoring high in all the categories listed, Brazil is well-known for being a case of historically low-levels of Party Institutionalization (Mainwaring, 1999). These differences are captured very clearly in the index, with the United States consistently scoring much higher than Brazil on the Party Institutionalization Index. Additionally, the index captures other historical dynamics in the countries that are worth mentioning given their contribution to elucidating the power of our index.

Starting with the United States, the data reveal a concave pattern. This should not come as a surprise to experts on American parties: the middle 1960s - the lowest point in the series - were times of ambiguous differentiation between Democrats and Republicans and lower levels of legislative cohesion - particularly as the contradictions between northern and southern democrats became more salient (Poole and Rosenthal, 2000). 


\section{Figure 6. Party Institutionalization in Brazil and the US}

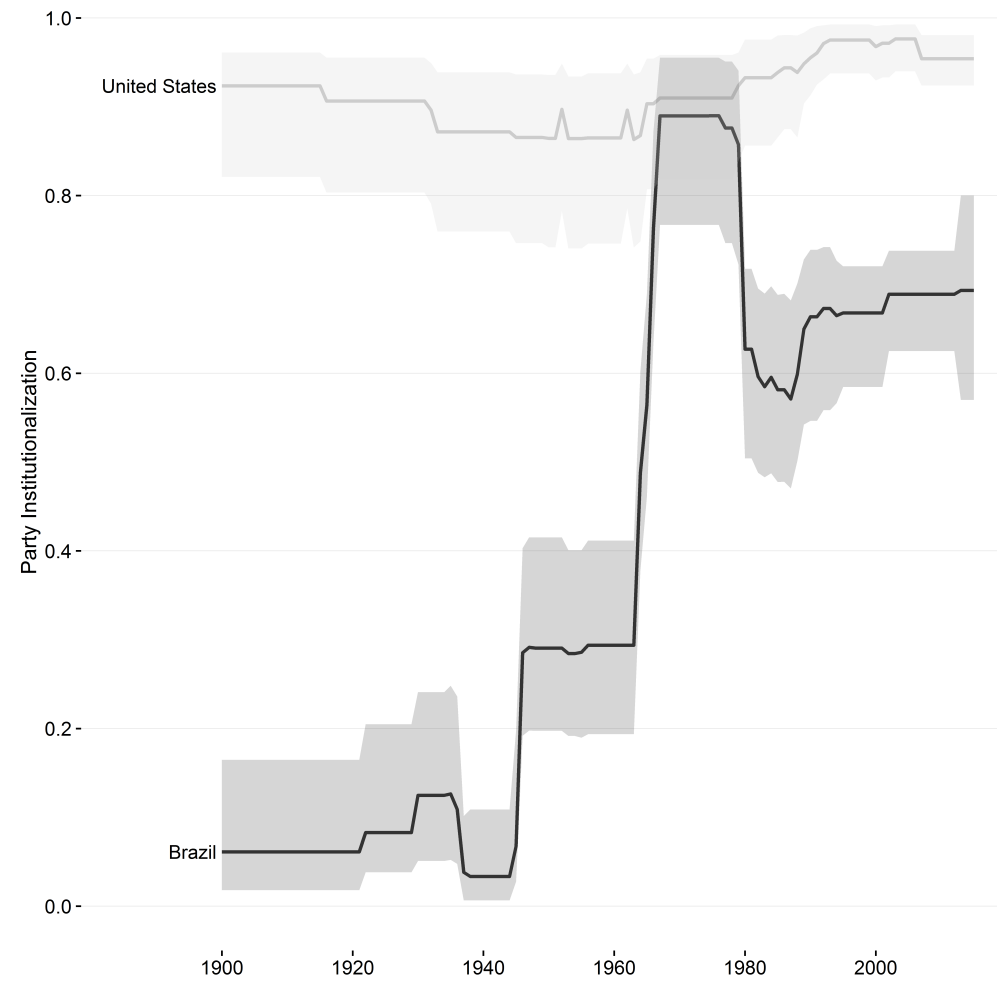

Turning to Brazil, readers will notice that the index for Brazil reaches its highest levels under military dictatorship (1964-1985). Although this seems initially contradictory, it is important to recall that the Brazilian authoritarian regime was a kind of competitive authoritarianism avantla-lettre, where a stable two-party system was established. The two parties had national organizations with regional penetration, had public and distinct platforms, and the levels of legislative cohesion were relatively high (Kinzo, 1985, Hagopian, 2007). Brazilian parties during that period though, do score low on the linkages question, a characteristics of Brazilian parties that is consistent across most of the twentieth century (Mainwaring, 1999).

If we move our analysis away from contemporary democracies and concentrate on authoritarian regimes, we again see how the V-Dem Party Institutionalization index captures the underlying dynamics of the countries we observe. We compare two communist regimes, Bulgaria (1945-1989) and Cuba (1959-) (Figure 7). While both regimes are marked by the prolonged reign of a single individual (Todor Zhivkov in Bulgaria, and Fidel Castro in Cuba), Cuba scores much lower than Bulgaria during the period. This difference reflects the conventional wisdom in comparisons between the Cuban regime and the countries in the Eastern bloc. Namely, that Communist parties played a much more important role in the latter. The end of communism and the dynamics following democratization in Bulgaria are also captured: levels of Party 
Institutionalization decline after 1989 and the country struggles to re-institutionalization after transition.

\section{Figure 7. Party Institutionalization in Bulgaria and Cuba}

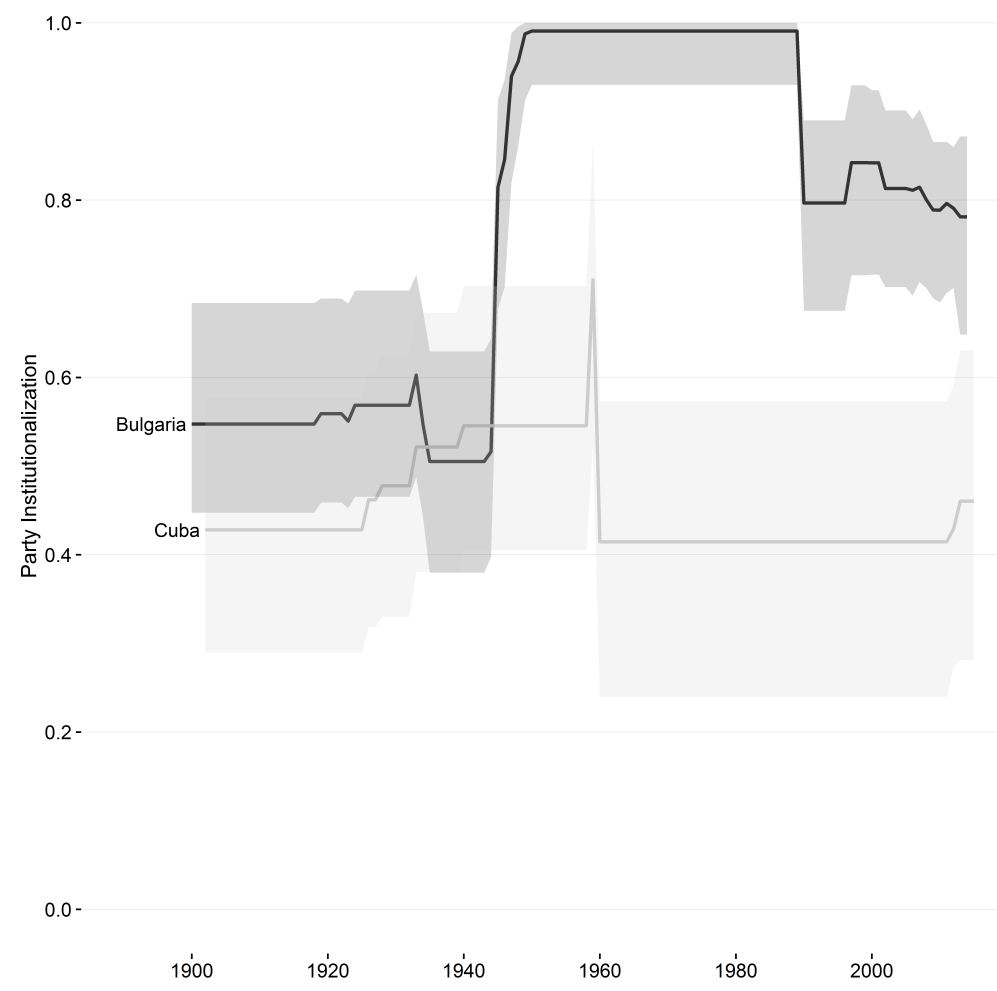

Finally, we take advantage of an existing index of party institutionalization to validate our new global index. Basedau and Stroh (2008) in their important contribution also provide the coding rules and scores for an index of party institutionalization measured for some African countries. Following their definitions, we compare the scores for the same 9 countries for which they build aggregate country-level indices of Party Institutionalization for the year of 2006. ${ }^{3}$ Figure 8 uses a scatter-plot to show this comparison. On the $\mathrm{x}$-axis we plot the values obtained in the $\mathrm{V}$ Dem Party Institutionalization Index, and on the y-axis we plot Basedau and Stroh's scores. The figure shows their close similarity $(r=0.69)$. Although the rank-order of the countries differ slightly (Tanzania and Ghana have the highest values in Basedau and Stroh's index, while in the V-Dem Index of Party Institutionalization they score only third and fourth; conversely, Botswana and Niger have the highest scores in our index and are placed third and fourth on theirs), the incorporation of V-Dem uncertainty estimates further demonstrates the similarities of the indices.

\footnotetext{
${ }^{3}$ We rescaled Basedau and Stroh's index from its original 0 to 8 scale to a 0 to 1 scale to facilitate the comparison.
} 
$1.0-$

$0.8-$

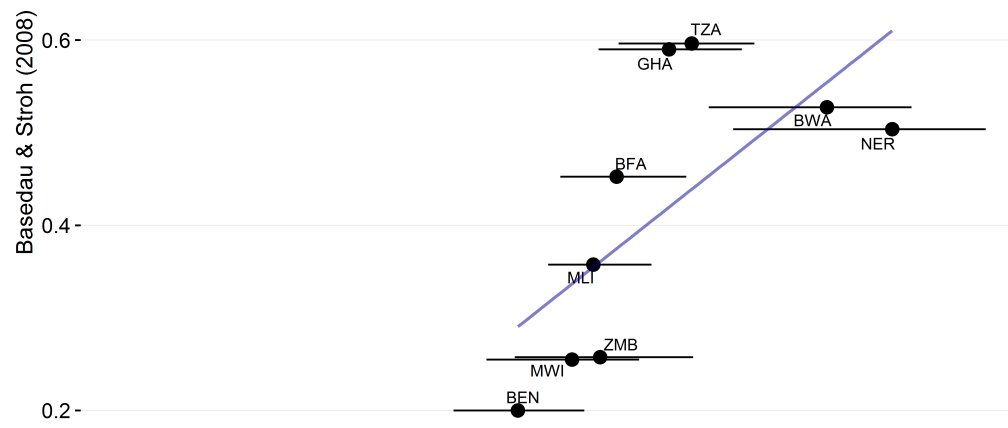

$0.0-$

These comparisons provide additional information about the potential of the V-Dem Party Institutionalization Index. The comparison with Basedau and Stroh's index also demonstrates how V-Dem can be helpful to scholars across the world: while most existing indices we use tend to cover only one or a few years, and only for a subset of countries, V-Dem provides reliable and valid scores for most countries in the world over a much longer period.

\section{Comparting the Party Institutionalization Index to Existing Indicators}

Finally, we investigate how the V-Dem Party Institutionalization Index compares to other measures that exist in the field. As we have discussed, operationalizing party and/or party system institutionalization has been an empirical challenge for comparative researchers. There are three common indicators that scholars have used: volatility, party age, and fragmentation. Measures of volatility typically rely on Pederson's (1979) volatility measure and produce summary statistics

${ }^{4}$ Countries included: Benin (BEN), Botswana (BWA), Burkina Faso (BFA), Ghana (GHA), Malawi (MWI), Mali (MLI), Niger (NER), Tanzania (TZA), Zambia (ZMB). 
based on changes in parties' vote or seat shares. (For critiques of this measure see Weghorst and Bernhard (2014) and Mainwaring et. al. (forthcoming).) Measures of party age report the average age of the largest parties in the system, while fragmentation is measured using the effective number of parties measure. Table 1 describes each indicator. For comparison purposes we also include several other indicators:

a) the Bartelsmann Transformation Index party system indicator, which is an expert coding of the extent to which there is a stable and socially rooted party system able to articulate and aggregate societal interests (www.bti-project.org).

b) Each of the components of the Party Institutionalization Index: party branches, party organization, party linkages, party cohesion, and party platforms.

c) The frequency of party switching, defined as the percentage $(\%)$ of the members of the national legislature changes or abandons their party in between elections (from VDem).

d) Extent to which national candidate selection is centralized within the parties (from VDem)

e) Party Strength. A measure devised by Bizzaro et. al. (2017) which measures the extent to which political parties within a polity are characterized by: (1) permanent national party organizations, (2) permanent local party branches, (3) centralized mechanisms of candidate selection, (4) legislative cohesion, (5) minimal party switching (where elected members of a party change their party affiliation in between elections), and (6) programmatic (rather than clientelistic) linkages to their social base.

\section{Table 1: Alternative Measures}

\begin{tabular}{|c|c|c|c|}
\hline Indicator & Description & Source & Coverage \\
\hline ENEP & Effective number of electoral parties & $\begin{array}{l}\text { The Anocracies } \\
\text { Dataset }^{5}\end{array}$ & $1945-2012$ \\
\hline Age & $\begin{array}{l}\text { The average age of the two largest } \\
\text { government parties and the largest } \\
\text { opposition party }\end{array}$ & World Bank/IADB ${ }^{6}$ & $1975-2015$ \\
\hline Volatility & Electoral volatility between elections & $\begin{array}{l}\text { Mainwaring et. al. } \\
\text { forthcoming }\end{array}$ & $1958-2015$ \\
\hline
\end{tabular}

\footnotetext{
${ }^{5}$ https:// sites.google.com/site/theanocracydataset/

${ }^{6}$ https://publications.iadb.org/handle/11319/7408
} 


\begin{tabular}{|c|c|c|c|}
\hline $\begin{array}{l}\text { BTI Party } \\
\text { System }\end{array}$ & $\begin{array}{l}\text { The extent to which there is a stable and } \\
\text { socially rooted party system able to } \\
\text { articulate and aggregate societal interests }\end{array}$ & $\begin{array}{l}\text { Bertelsmann } \\
\text { Transformation } \\
\text { Index }^{7}\end{array}$ & $2003-2016$ \\
\hline Branches & $\begin{array}{l}\text { Extent to which parties have permanent } \\
\text { local party branches }\end{array}$ & V-Dem & $1900-2016$ \\
\hline Organization & $\begin{array}{l}\text { Extent to which political parties have } \\
\text { permanent organizations }\end{array}$ & V-Dem & $1900-2016$ \\
\hline Links & $\begin{array}{l}\text { Nature of linkages between parties and } \\
\text { their constituents }\end{array}$ & V-Dem & $1900-2016$ \\
\hline Cohesion & Degree of legislative party cohesion & V-Dem & $1900-2016$ \\
\hline Platforms & $\begin{array}{l}\text { Extent to which parties have publicly } \\
\text { available party platforms (manifestos) } \\
\text { that are distinct from one another }\end{array}$ & V-Dem & $1900-2016$ \\
\hline $\begin{array}{l}\text { Party } \\
\text { Switching }\end{array}$ & Frequency of party switching & V-Dem & $1900-2016$ \\
\hline Selection & $\begin{array}{l}\text { Extent to which candidate selection is } \\
\text { centralized within the parties }\end{array}$ & V-Dem & 1900-2016 \\
\hline Party Strength & $\begin{array}{l}\text { Extent to which political parties are } \\
\text { unified, centralized, organizationally } \\
\text { complex with mass constituencies }\end{array}$ & Bizzaro et. al. 2017 & $1900-2016$ \\
\hline
\end{tabular}

Figure 9 below displays the correlation coefficients between our Party Institutionalization index and these three common measures of institutionalization. Our party institutionalization measure performs as we would expect vis-à-vis these other indicators. Among the traditional indicators of institutionalization our indicator it is moderately and negatively correlated with electoral volatility, weakly and positively correlated with party age, and unrelated to party system fragmentation. ${ }^{8}$ The V-Dem Party Institutionalization Index is also correlated with BTI's party system indicator at the .66 level. Turning to V-Dem indicators, not surprisingly the Index is strongly correlated with its constituent indicators, particularly branches, organizations, and platforms. It is also strongly correlated with Bizzaro et. al.'s Party Strength measure-not surprising given that Party Strength relies on several of the same indicators as our Index. In summary, the results of this correlation exercise is reassuring. Countries with more institutionalized parties in our index have lower

\footnotetext{
${ }^{7}$ www.bti-project.org

8 Fragmentation is weakly correlated with only party switching and electoral volatility.
} 
electoral volatility, parties that are, on average, older, and were identified as institutionalized by alternative measures. The correlation, nevertheless, is far from perfect, suggesting that our Index captures some aspects of institutionalization that existing indicators do not.

Figure 9: Correlation with Other Measures

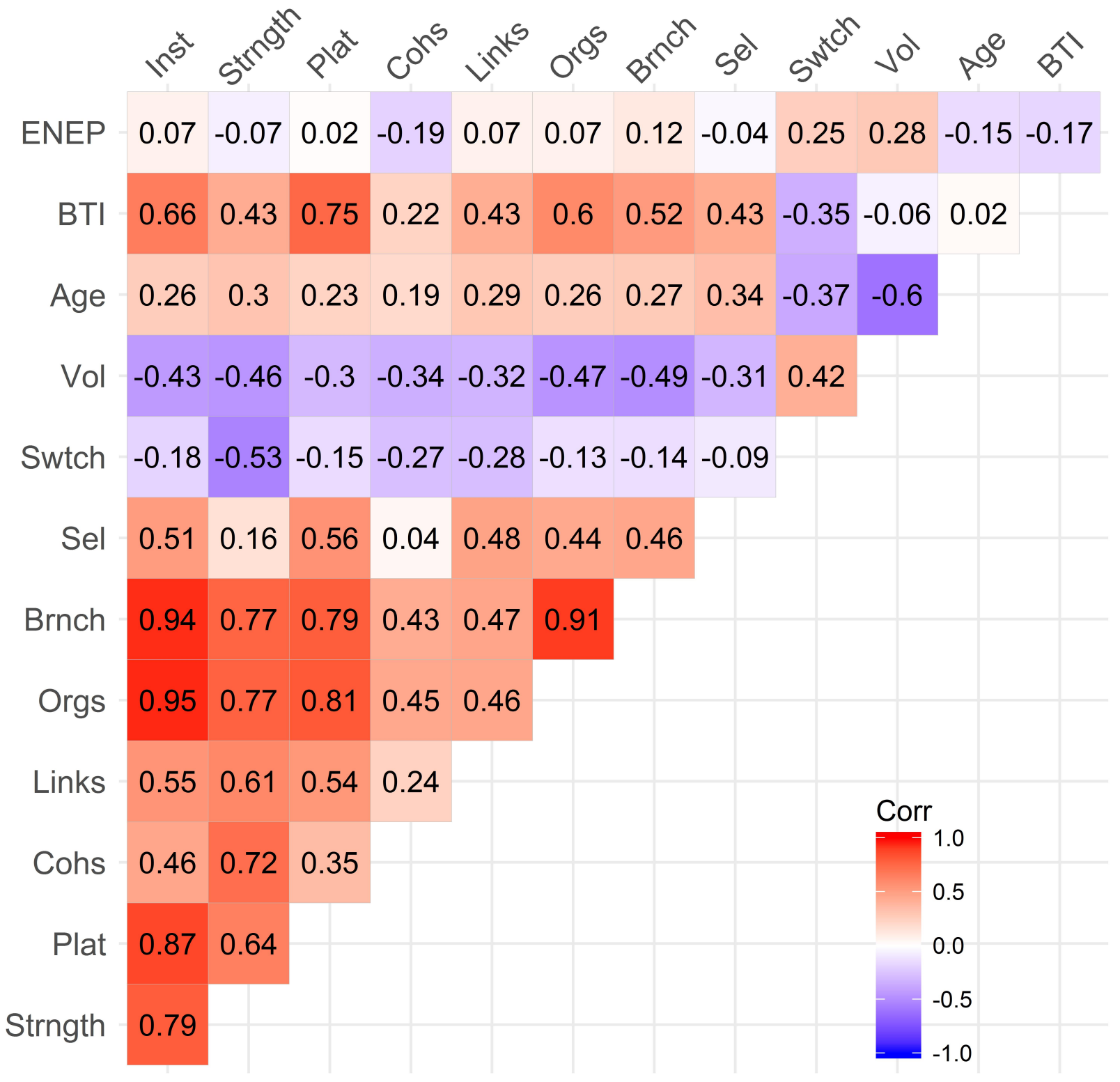




\section{Conclusion}

This article introduced the V-Dem Party Institutionalization Index, explained the theory that underlies the index construction, and test in multiple ways the validity and the reliability of the estimates. We follow McMann et al. (2016) in arguing that we should aim for indicators that meet the "good enough" threshold. We have tried to demonstrate that the Party Institutionalization Index we create is indeed good enough--that is, it is reliable, and valid. Moreover, we have tried to connect some of those indicators and the V-Dem Party Institutionalization Index in empirical and theoretically meaningful ways.

We believe that it may now open a new set of possibilities for scholars researching about political parties. In other works, we have already started applying the variables in the V-Dem dataset regarding political parties to better understand many important outcomes. Bizzarro and his co-authors (2015), for example, found that countries with stronger parties tend to have consistently higher levels of economic growth, providing important contribution to the literature about the institutional determinants of political economy outcomes. Similarly, Bernhard and his co-authors (2015) used a previous version of this same index as a predictor of Democratic stability and found that stronger parties protect democracy: countries with more institutionalized parties have lower risk of experiencing democratic breakdown, even after controlling for many usual determinants of democratic stability - as GDP per capita. Scholars can now follow these steps and find innovative ways to bring parties to their analysis of political outcomes.

Scholars may also advance our understanding of the determinants of variations in levels of party institutionalization, as well as variations in the individual questions about parties included in the dataset. We can now know more about the types of linkages parties predominantly establish with voters and understand where clientelistic and programmatic linkages tend to emerge. We can also expand our understanding of legislatures beyond the existing finds that have relied exclusively on roll call data. These and other contributions are now in the reach of scholars researching parties globally and this article is a first step in order to make these contributions advance. 


\section{References}

BASEDAU, M. \& STROH, A. 2008. Measuring party institutionalization in developing countries. Working Paper Series, German Institute of Global and Area Studies.

BERNHARD, M., HICKEN, A. \& REMMOCK, C. 2015. Institutional Subsystems and the Survival of Democracy: Do political and civil society matter? V-Dem Working Paper, 4.

BIZZARRO, F., GERRING, J., KNUTSEN, C.-H., HICKEN, A., BERNHARD, M., SKAANING, S.-E., COPPEDGE, M. \& LINDBERG, S. 2015. Party Strength and Economic Growth. V-Dem Working Paper Series, 10.

BOIX, C., MILLER, M. \& ROSATO, S. 2012. A complete data set of political regimes, 18002007. Comparative Political Studies, 0010414012463905.

BROWNLEE, J. 2007. Authoritarianism in an age of democratization, Cambridge, Cambridge University Press.

COPPEDGE, M. 2012. Democratization and research methods, Cambridge University Press.

COPPEDGE, M., GERRING, J., ALTMAN, D., BERNHARD, M., FISH, S., HICKEN, A., KROENIG, M., LINDBERG, S. I., MCMANN, K., PAXTON, P., SEMETKO, H. A., SKAANING, S.-E., STATON, J. \& TEORELL, J. 2011. Conceptualizing and Measuring Democracy: A New Approach. Perspectives on Politics, 9, 247-267.

COPPEDGE, M., GERRING, J., LINDBERG, S., SKAANING, S.-E., TEORELL, J., ALTMAN, D., ANDERSOON, F., BERNHARD, M., FISH, M. S., GLYNN, A., HICKEN, A., KNUTSEN, C.-H., MCMANN, K., MECHKOVA, V., MIRI, F., PAXTON, P., PEMSTEIN, D., SIGMAN, R., STATON, J. \& ZIMMERMAN, B. 2016 a. Varieties of Democracy Codebook v6. Gothenburg: V-Dem Institute.

COPPEDGE, M., GERRING, J., LINDBERG, S., SKAANING, S.-E., TEORELL, J., ALTMAN, D., ANDERSOON, F., BERNHARD, M., FISH, M. S., GLYNN, A., HICKEN, A., KNUTSEN, C.-H., MCMANN, K., MECHKOVA, V., MIRI, F., PAXTON, P., PEMSTEIN, D., SIGMAN, R., STATON, J. \& ZIMMERMAN, B. 2016b. Varieties of Democracy Dataset v6. In: INSTITUTE, V.-D. (ed.). Gothenburg.

COPPEDGE, M., GERRING, J., LINDBERG, S., SKAANING, S.-E., TEORELL, J., ANDERSOON, F., MECHKOVA, V., PERNES, J. \& STEPANOVA, N. 2016c. V-Dem Organization and Management v6. In: INSTITUTE, V.-D. (ed.). Gothenburg: V-Dem Institute.

FJELDE, H. 2010. Generals, Dictators, and Kings Authoritarian Regimes and Civil Conflict, 1973-2004. Conflict Management and Peace Science, 27, 195-218.

GANDHI, J. 2008. Political institutions under dictatorship, New York, Cambridge University Press.

GEDDES, B., WRIGHT, J. \& FRANTZ, E. 2014. Autocratic breakdown and regime transitions: A new data set. Perspectives on Politics, 12, 313-331.

GEHLBACH, S. \& KEEFER, P. 2011. Investment without democracy: Ruling-party institutionalization and credible commitment in autocracies. Journal of Comparative Economics, 39, 123-139.

GEHLBACH, S. \& KEEFER, P. 2012. Private investment and the institutionalization of collective action in autocracies: ruling parties and legislatures. The Journal of Politics, 74, 621 635. 
GRZYMALA-BUSSE, A. M. 2002. Redeeming the communist past: The regeneration of communist parties in East Central Europe, Cambridge University Press.

HAGOPIAN, F. 2007. Traditional politics and regime change in Brazil, Cambridge University Press.

HICKEN, A. 2016. Party Systems and the Politics of Development. In: CAROL, L. \& NICOLAS VAN DE, W. (eds.) The Oxford Handbook of Politics of Development. Oxford: Oxford University Press.

HICKEN, A. \& KUHONTA, E. M. 2014. Introduction: Rethinking Party System Institutionalization in Asia. In: HICKEN, A. \& KUHONTA, E. M. (eds.) Party system institutionalization in Asia: democracies, autocracies, and the shadows of the past. Cambridge: Cambridge University Press.

HUNTINGTON, S. P. 1968. Political order in changing societies, New Haven, Yale University Press.

IGNAZI, P. 1996. The Crisis of Parties and the Rise of New Political Parties. Party Politics, 2, 549566.

KATZ, R. S. 1980. A theory of parties and electoral systems, Baltimore, Johns Hopkins University Press.

KEY, V. O. 1964. Politics, parties, and pressure groups, New York, Cronwell.

KINZO, M. A. 1985. An opposition party in an authoritarian regime: the case of the MDB (Movimento Democratico Brasileiro) in Brazil, 1966-1979. University of Oxford.

KITSCHELT, H. 2013. Democratic Accountability and Linkages Project. Durham: Duke University.

KITSCHELT, H. \& WILKINSON, S. I. 2007. Patrons, clients and policies: Patterns of democratic accountability and political competition, Cambridge University Press.

KOLLMAN, K., HICKEN, A., CARAMANI, D., BACKER, D. \& LUBLIN, D. 2016. Constituency-Level Elections Archive. In: CENTER FOR POLITICAL STUDIES, U. O. M. (ed.). Ann Arbor, MI: Center for Political Studies, University of Michigan.

LEVITSKY, S. 2003. Transforming labor-based parties in Latin America: Argentine Peronism in comparative perspective, Cambridge University Press.

LEVITSKY, S. \& WAY, L. A. 2010. Competitive authoritarianism: Hybrid regimes after the cold war, Cambridge University Press.

MAGALONI, B. 2006. Voting for autocracy : hegemonic party survival and its demise in Mexico, Cambridge, Cambridge University Press.

MAINWARING, S. 1999. Rethinking party systems in the third wave of democratization: the case of Brazil, Stanford University Press.

MAINWARING, S., BIZZARRO, F. \& PETROVA, A. Forthcoming. Introduction. In: MAINWARING, S. (ed.) Party Systems in Latin America. Cambridge: Cambridge University Press.

MAINWARING, S., GERVASONI, C. \& ESPAÑA-NAJERA, A. 2016. Extra- and withinsystem electoral volatility. Party Politics.

MAINWARING, S. \& SCULLY, T. 1995. Building democratic institutions : party systems in Latin America, Stanford, Stanford University Press.

MCMANN, K., PEMSTEIN, D., SEIM, B., TEORELL, J. \& LINDBERG, S. I. 2016. Strategies of Validation: Assessing the Varieties of Democracy Corruption Data. Gothenburg: VDem Institute Working Paper Series. 
MILLER, M. K. 2015. Electoral authoritarianism and human development. Comparative Political Studies, 0010414015582051.

MÜLLER, W. C. \& STRØM, K. 1999. Policy, office, or votes?: how political parties in Western Europe make hard decisions, Cambridge University Press.

OLSON, M. 2009. The logic of collective action, Harvard University Press.

PANEBIANCO, A. 1988. Political parties: organization and powver, Cambridge, Cambridge University Press.

PEDERSEN, M.N. 1979. The Dynamics of European Party Systems: Changing Patterns of Electoral Volatility. European Journal of Political Research. 7: 1-26.

PEMSTEIN, D., MARQUARDT, K., TZELGOV, E., WANG, Y.-T. \& MIRI, F. 2015. The VDem Measurement Model: Latent Variable Analysis for Cross-National and CrossTemporal Expert-Coded Data. Gothenburg: V-Dem Institute.

POGUNTKE, T., SCARROW, S. E., WEBB, P. D., ALLERN, E. H., AYLOT'T, N., VAN BIEZEN, I., CALOSSI, E., LOBO, M. C., CROSS, W. P., DESCHOUWER, K., ENYEDI, Z., FABRE, E., FARRELL, D. M., GAUJA, A., PIZZIMENTI, E., KOPECKÝ, P., KOOLE, R., MÜLLER, W. C., KOSIARA-PEDERSEN, K., RAHAT, G., SZCZERBIAK, A., VAN HAUTE, E. \& VERGE, T. 2016. Party rules, party resources and the politics of parliamentary democracies: How parties organize in the $21 \mathrm{st}$ century. Party Politics, 22, 661-678.

POOLE, K. T. \& ROSENTHAL, H. 2000. Congress: A political-economic history of roll call voting, Oxford University Press on Demand.

SARTORI, G. 2005. Parties and party systems: A framework for analysis, ECPR press.

SCHATTSCHNEIDER, E. E. 2003. Party government, Piscataway, New Jersey, Transaction Publishers.

SMITH, B. 2005. Life of the party: The origins of regime breakdown and persistence under singleparty rule. World Politics, 57, 421-451.

SVOLIK, M. W. 2012. The politics of authoritarian rule, Cambridge, Cambridge University Press.

TAVITS, M. 2013. Post-communist democracies and party organization, Cambridge University Press.

VOLKENS, A., LEHMANN, P., MATTTHIEß, T., MERZ, N., REGEL, S. \& WERNER, A. 2016. The Manifesto Data Collection. Manifesto Project (MRG/CMP/MARPOR). Version 2016a ed. Berlin: Wissenschaftszentrum Berlin für Sozialforschung (WZB)

WEGHORST, KEITH R. \& MICHAEL BERNHARD. 2014. From Formlessness to Structure? The Institutionalizationof Party Systems in Africa. Comparative Political Studies. 47(12): 1707-1737. 


\section{Appendix}

\section{Table A1. Other Party Variables}

\section{Party ban (C) (v2psparban)}

Question: Are any parties banned?

Clarification: This does not apply to parties that are barred from competing for failing to meet registration requirements or support thresholds.

Responses:

0: Yes. All parties except the state-sponsored party (and closely allied parties) are banned.

1: Yes. Elections are non-partisan or there are no officially recognized parties.

2: Yes. Many parties are banned.

3: Yes. But only a few parties are banned.

4: No. No parties are officially banned.

Scale: Ordinal, converted to interval by the measurement model.

\section{Barriers to parties (C) (v2psbars)}

Question: How restrictive are the barriers to forming a party?

Clarification: Barriers include legal requirements such as requirements for membership or financial deposits, as well as harassment.

Responses:

0 : Parties are not allowed.

1: It is impossible, or virtually impossible, for parties not affiliated with the government to form (legally).

2: There are significant obstacles (e.g. party leaders face high levels of regular political harassment by authorities).

3: There are modest barriers (e.g. party leaders face occasional political harassment by authorities).

4: There are no substantial barriers.

Scale: Ordinal, converted to interval by the measurement model.

\section{Opposition parties autonomy (C) (v2psoppaut)}

Question: Are opposition parties independent and autonomous of the ruling regime?

Clarification: An opposition party is any party that is not part of the government, i.e., that has no control over the executive.

Responses:

0: Opposition parties are not allowed.

1: There are no autonomous, independent opposition parties. Opposition parties are either selected or co-opted by the ruling regime.

2: At least some opposition parties are autonomous and independent of the ruling regime.

3: Most significant opposition parties are autonomous and independent of the ruling regime.

4: All opposition parties are autonomous and independent of the ruling regime.

Ordering: Answer only if previous question (v2psbars) is coded 1-4.

Scale: Ordinal, converted to interval by the measurement model.

\section{Candidate selection-national/local (C) (v2pscnslnl)}

Question: How centralized is legislative candidate selection within the parties?

Clarification: The power to select candidates for national legislative elections is often

divided between local/municipal party actors, regional/state-level party organizations, and national party leaders. One level usually dominates the selection process, while sometimes candidate selection is the outcome of bargaining between the different levels of party organization.

Responses: 
0: National legislative candidates are selected exclusively by national party leaders.

1: National legislative candidate selection is dominated by national party leaders but with some limited influence from local or state level organizations.

2: National legislative candidates are chosen through bargaining across different levels of party organization.

3: National legislative candidates are chosen by regional or state-level organizations, perhaps with some input from local party organizations or constituency groups.

4: National legislative candidates are chosen by a small cadre of local or municipal level actors.

5: National legislative candidates are chosen by constituency groups or direct primaries.

Scale: Ordinal, converted to interval by the measurement model.

\section{Party switching (C) (v2psswitch)}

Question: Roughly what percentage $(\%)$ of the members of the national legislature changes or abandons their party in between elections?

Clarification: Do not include official party splits (when one party divides into two or more parties) or dissolutions (when a party formally dissolves).

Responses: Percent

Scale: Interval

Cross-coder aggregation: Bootstrapped.

\section{Party competition across regions (C) (v2pscomprg)}

Question: Which of the following best describes the nature of electoral support for major parties (those gaining over $10 \%$ of the vote)?

Clarification: Leave this question blank if election was nonpartisan, i.e., no parties (not even progovernment parties) were allowed.

Responses:

0: Most major parties are competitive in only one or two regions of the country, i.e., their support is heavily concentrated in a few areas.

1: Most major parties are competitive in some regions of the country, but not in others.

2: Most major parties are competitive in most regions of the country.

Scale: Ordinal, converted to interval by the measurement model.

\section{Subnational party control (C) (v2pssunpar)}

Question: Does a single party control important policymaking bodies across subnational units (regional and local governments)?

Clarification: Leave this question blank if election was nonpartisan, i.e., no parties (not even progovernment parties) were allowed.

Responses:

0: In almost all subnational units (at least 90\%), a single party controls all or virtually all policymaking bodies.

1: In most subnational units (66\%-90\%), a single party controls all or virtually all policymaking bodies.

2: In few subnational units (less than $66 \%$ ), a single party controls all or virtually all policymaking bodies.

Scale: Ordinal, converted to interval by the measurement model. 